\title{
Card-Based Delivery Date Promising in Pure Flow Shops with Order Release Control
}

Matthias Thürer (corresponding author) and Mark Stevenson

$\begin{array}{ll}\text { Name: } & \text { Prof. Matthias Thürer } \\ \text { Institution: } & \text { Jinan University } \\ \text { Address: } & \text { Jinan University } \\ & \begin{array}{l}\text { No 601, Huangpu Road } \\ \text { 510632 Guangzhou, PR China }\end{array} \\ & \text { matthiasthurer@workloadcontrol.com } \\ \text { E-mail: } & \text { Prof. Mark Stevenson } \\ \text { Name: } & \text { Lancaster University } \\ \text { Institution: } & \text { Department of Management Science } \\ \text { Address: } & \text { Lancaster University Management School } \\ & \text { Lancaster University } \\ & \text { LA1 4YX - U.K. } \\ \text { m.stevenson@lancaster.ac.uk }\end{array}$

Keywords: Workload Control; Card-based Control; Pure Flow Shop; Customer Enquiry Management; COBACABANA. 


\title{
Card-Based Delivery Date Promising in Pure Flow Shops with Order Release Control
}

\begin{abstract}
Card-based systems are simple, effective means of controlling production. Yet most systems concentrate on controlling the shop floor. They neglect other planning tasks, like estimating short, feasible due dates during customer enquiry management. A card-based version of the Workload Control concept for job shops - COBACABANA (Ontrol of BAlance by $\underline{\text { CArd- }}$ BAsed Navigation) - was proposed in the literature to overcome this shortcoming. COBACABANA uses cards for due date setting and order release, making it a potentially important solution for small shops with limited resources. But many such firms operate as flow shops rather than job shops. Research demonstrated that COBACABANA's release mechanism must be adapted if applied to a pure flow shop, but its approach to due date setting has not been evaluated in such an environment. We show COBACABANA has the potential to improve pure flow shop performance, but its due date setting procedure should be adapted compared to job shops. In a flow shop, due date estimation can also be further simplified by considering the load awaiting release to the first (gateway) station only while maintaining most performance benefits. The results are important for all card-based systems that aim to stabilize work-in-process, including kanban and ConWIP (Constant Work-in-Process).

Keywords: Workload Control; Card-based Control; Pure Flow Shop; Customer Enquiry Management; COBACABANA.
\end{abstract}




\section{Introduction}

Card-based systems, such as kanban (e.g. Sugimuri et al., 1977; Shingo, 1989), Constant Workin-Process (ConWIP; e.g. Spearman et al., 1990; Hopp \& Spearman, 1996) and Paired-cell Overlapping Loops of Cards with Authorization (POLCA; e.g. Suri, 1998; Riezebos, 2010), provide a simple, visual approach to controlling production. They are consequently widely applied in practice (e.g. White et al., 1999; White \& Prybutok, 2001; Slomp et al., 2009; Krishnamurthy \& Suri, 2009; Riezebos, 2010). Yet, existing card-based systems concentrate on controlling the release of orders to the shop floor and/or on the flow of orders between stations. They do not support other higher level planning tasks, such as estimating due dates during customer enquiry management. This limits the advantage of using a simple, card-based control system as it means companies have to maintain some other sophisticated planning and control processes to support these tasks. For example, Spearman et al. (1989) proposed a rather complex Hierarchical Control Architecture for supporting the implementation of ConWIP; and Riezebos et al. (2009) emphasized the importance of an IT system for ConWIP to be effective. Meanwhile, in Suri (2003), Quick Response Manufacturing (QRM) Principle 5 concerns the use of a Material Requirements Planning (MRP) system for higher level planning as a pre-requisite to the use of the POLCA card-based system on the shop floor.

To the best of our knowledge, the only card-based system that incorporates card-based order

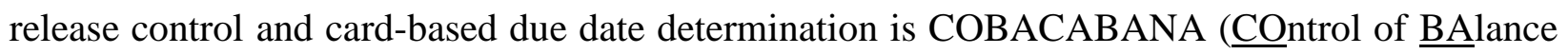

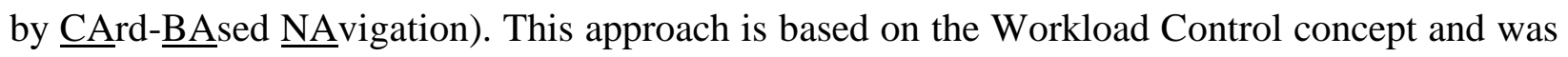
originally developed by Land (2009). Both aspects of COBACABANA - due date estimation and order release - have recently been refined and their effectiveness demonstrated by Thürer $e t$ al. (2014b and 2015a). However, all three of these studies (i.e. Land, 2009; Thürer et al., 2014b and 2015a) focused on job shops, where the number of stations in the routing of a job and the sequence in which stations are visited varies. This environment is different to the pure flow job shop - where all jobs have to visit all stations in the same sequence - for which traditional cardbased systems were developed. Thürer et al. (2015b) recently highlighted the potential of COBACABANA's release method as an alternative to kanban systems in pure flow shops if there is high variability in terms of the occurrence of demand and processing times as it is able to balance the load across stations. However, the original release mechanism developed for job shops was found to be dysfunctional. More specifically, the gateway station that is inherent to a 
pure flow shop meant the approach had to be adjusted. Although Thürer et al. (2015b) examined COBACABANA's approach to order release control in the pure flow shop, its approach to estimating due dates has been neglected. It appears likely however that this too may be in need of refinement.

In response, this study extends Thürer et al. (2015b) - simulation is used to explore the performance of COBACABANA in a pure flow shop where the flow of jobs is controlled. In doing so, we (i) evaluate the performance of COBACABANA as a system that integrates due date estimation and order release control in a pure flow shop and (ii) assess the need to adapt COBACABANA's due date estimation procedure for application in a pure flow shop, where jobs visit all stations in the same sequence. We focus on a pure flow shop with high variability in demand and/or processing times since it is highly variable environments in which COBACABANA is argued to yield the most benefits compared to 'traditional' card-based systems (Thürer et al., 2015b). The pure flow shop with high variability is a common shop type, e.g. for companies that focus on producing prototypes and making small runs, e.g. of 1 to 4 units, sometimes referred to as "one offs". Similarly, Portioli-Staudacher \& Tantardini (2011) recently argued that many non-repetitive companies have started to implement lean, resulting in more streamlined production flows. These streamlined production flows are a defining characteristic of the pure flow shop. Meanwhile, our findings will also have major implications for more repetitive flow shops where kanban and ConWIP may be applied to control the shop floor. This is particularly important for small shops with limited resources, which often struggle to implement Manufacturing Resource Planning (MRP) or Enterprise Resource Planning (ERP) software for higher level planning (e.g. Aslan et al., 2015). The simple card-based solution provided by COBACABANA could potentially take over this role in the future.

The remainder of this paper is organized as follows. COBACABANA is first described in Section 2 before Section 3 outlines the simulation model of the pure flow shop used to examine its performance. The results are then presented and discussed in Section 4. Finally, concluding remarks are made in Section 5, where managerial implications and future research directions are also outlined. 


\section{COBACABANA - A Simple Card-Based Approach to Workload Control}

COBACABANA is based on the Workload Control concept (e.g. Fredendall et al., 2010; Hendry et al., 2013; Thürer et al. 2012, 2014a) that integrates two control levels: Order Release; and Customer Enquiry Management. COBACABANA translates the information flow of Workload Control into cards. Its order release mechanism is discussed first in Section 2.1 below before Section 2.2 focuses on due date estimation, which is the main focus of our study. The overall COBACABANA system is then summarized in Section 2.3 .

\subsection{COBACABANA: Card-Based Order Release}

COBACABANA stabilizes the shop floor workload through the use of order release control. The order release method outlined here follows the refinements proposed by Thürer et al. (2014b) to Land's (2009) original card-based concept. COBACABANA establishes card loops between the planner performing the order release decision and each station on the shop floor. The release decision will first be discussed in Section 2.1.1 before Section 2.1.2 outlines when the release decision takes place, i.e. the timing of release.

\subsubsection{COBACABANA's Release Decision}

Orders in the pool are sorted according to their due date. Beginning with the first order in the sequence, the subset of orders to be released from the pool is then determined by considering all orders in the pool for release once. Each operation in a job has one release card and one operation card. The size of the release card represents the corrected workload of the operation. The corrected workload is obtained by dividing the processing time of the operation at a station by the station's position in the job's routing (Oosterman et al., 2000). It is different from the aggregate load, which is a measure of the full processing time. Correcting the aggregate load recognizes that, in the long run, the card for the second operation stays on the shop floor approximately twice as long as the card for the first operation. Oosterman et al. (2000) showed how using this correction leads to the most stable direct load buffer (i.e. the load queuing directly in front of a station) compared to other approaches of accounting for the workload over time.

To consider an order for release, the planner places the release card that corresponds to the corrected workload of the order at each station in its routing in the area dedicated to each station on a planning board. The planner then compares the workload of each station with predetermined workload limits or norms. If, for any station in the routing of an order, the workload represented 
by the release cards on the planning board (the existing workload plus the new order's workload) exceeds the workload limit, the order is retained in the pool and the order's release cards are removed from the planning board. Otherwise, the order's release cards remain on the planning board, the planner attaches the corresponding operation cards to an order guidance form that travels with an order through the shop, and the order is released. Each operation card is returned to the planner after the operation has been completed at a station. This closes the information loop and signals to the planner that he/she can remove the corresponding release card from the planning board.

\subsubsection{Timing of Order Release}

Thürer et al. (2014b) and Land (2009), in the context of a pure job shop, activated the above release decision at periodic time intervals. On its own, this approach may lead to so-called premature idleness (see Kanet, 1988; Land \& Gaalman, 1998), which can result from the strict enforcement of norms in combination with periodic release. Since a job has to fit the norm at all stations in its routing, it is possible that a station may be starving even though a job that can be processed directly at this station is waiting in the pool. This job may be being held up in the pool because its release would violate the norm of another station - hence, the first station becomes idle prematurely. Consequently, Thürer et al. (2014b) combined periodic release with a continuous trigger that, at any time, releases work that can be processed directly at a station if this station is in danger of starving, irrespective of whether the job violates the norm of another upstream station. However, Thürer et al. (2015b) demonstrated that this starvation avoidance trigger becomes dysfunctional in the pure flow shop since all work is released to the first (gateway) station. As a result, COBACABANA's release mechanism has to be adapted if it is to be used in a pure flow shop. Rather than executing the main release decision at periodic time intervals, it is executed continuously whenever a new job arrives to the shop or an operation is completed. Thus, COBACABANA transforms from a release method that takes the release decision periodically and continuously into a purely continuous release method.

\subsection{COBACABANA: Card-Based Due Date Estimation}

Customer enquiry management performs two functions within COBACABANA. First, it stabilizes the planned workload by controlling the acceptance/rejection of orders. Second, it ensures short, feasible delivery time allowances or due dates. In fact, Thürer et al. (2014a) 
demonstrated that these two functions can be combined if due dates are feasible and reflect a firm’s actual operational capabilities.

Order release divides the planned workload into two parts: the load in the pre-shop pool and the load on the shop floor. Hence, the delivery time allowance can be divided into an allowance for the pre-shop pool waiting time and an allowance for the shop floor throughput time. As described above, COBACABANA uses the order release mechanism to control the amount of work on the shop floor. Variability in the planned workload is shifted from the shop floor to the pre-shop pool (Melnyk \& Ragatz, 1989; Thürer et al., 2012); therefore, only the pre-shop pool waiting time is considered to vary. Since the shop floor workload is stabilized, the allowance for the shop floor throughput time (i.e. the time from release to completion) is considered to be a constant. This allowance should accurately represent realized shop floor throughput times, with any variability captured by a third (in addition to the allowance for pool waiting and shop floor throughput time) external allowance that allows managers to trade-off tight due dates against delivery reliability (e.g. Bertrand, 1983; Enns, 1995; Hopp \& Sturgis, 2000).

Note that stabilized work-in-process and, consequently, shop floor throughput times are also the main objective of traditional card-based systems, i.e. kanban, ConWIP and POLCA. Therefore, although our study focuses on COBACABANA release, with its unique load balancing capability, the logic underlying COBACABANA's due date estimation procedure could also potentially be combined with any of these other systems.

Considering shop floor throughput times as constant substantially reduces the requirements for information feedback from the shop floor during due date estimation at customer enquiry management. This allows COBACABANA to estimate due dates using cards. COBACABANA estimates the due date $\left(d_{j}\right)$ of a newly arrived job $j$ at time $t$ by Equation (1) below, where $\alpha$ is a variable allowance for the time that the order has to wait in the pre-shop pool prior to release; $\beta$ is a constant allowance for the shop floor throughput time; and, $\gamma$ is an allowance for external variability between the calculated delivery time and the ultimately realized delivery time.

$d_{j}=t+\alpha+\beta+\gamma$

Note that Land (2009) and Thürer et al. (2015a) considered operation throughput times rather than the shop floor throughput time to be constant. This is because in a pure job shop - as 
considered in these earlier studies - the number of operations in the routing of an order may vary. In contrast, in the pure flow shop, all jobs visit all stations. Thus, if operation throughput times are constant, shop floor throughput times are also constant.

\subsubsection{The Due Date Estimation Procedure}

COBACABANA establishes card loops between customer enquiry management and the preshop pool. The procedure outlined here follows Thürer et al. (2015a) whereby there is a pair of cards for each operation: one acceptance card and one pool card. The acceptance cards are used to visualize the workload waiting to be released in the pre-shop pool. Meanwhile, the pool cards are used to signal the release of a job.

The size of each acceptance card reflects the operation's workload contribution to the pool load of a particular station on the salesperson's display, as depicted in Figure 1. When an order arrives at the shop, an appropriate allowance for the pool waiting time is calculated based on Little’s Law (Little, 1961), i.e. we divide a measure of the pool load by the expected rate at which jobs are released. The pool load is represented by the cards and the expected release rate is represented by the scale used on the salesperson's display, i.e. the distance between two markers indicates the quantity of work (expressed by the cards) that is expected to be released per time unit (days in Figure 1). Once a due date has been determined, the pool cards are attached to the order guidance form and the order is moved into the pool to await release by the planner. When the order has been released, the pool cards return to the salesperson at customer enquiry management and the corresponding acceptance cards are withdrawn from the salesperson's display.

\section{[Take in Figure 1]}

COBACABANA's due date estimation procedure has been shown to significantly improve performance in pure job shops. However, its performance effect in a pure flow shop has not been assessed. This is a major shortcoming since it has recently been shown that COBACABANA's release method cannot be directly implemented in this environment. In response, three different measures of the pool load and corresponding release rate will be considered in this study:

(i) Aggregate Load: This approach uses: the total processing time units waiting in the pool to be released to the station that is most likely to be the most constrained station (i.e. the station in the job's routing with the largest load in the pre-shop pool); and, the throughput rate of this 
station (i.e. the maximum output per time unit). Using the aggregate load of the most constrained station recognizes that the bottleneck controls the process. These are the original measures proposed by Land (2009).

(ii) Corrected Load: This approach uses: the corrected processing time units waiting in the pool to be released to the station that is most likely to be the most constrained station (i.e. the station in the job's routing with the largest load in the pre-shop pool); and, the release rate measured in terms of the corrected aggregate load (i.e. the throughput rate corrected by the average routing position of stations across jobs). This refinement to Land's (2009) above measure was proposed by Thürer et al. (2015a) to account for short-term fluctuations at release since, in the short-term, the release rate is determined by the corrected aggregate load and not by the rate at which jobs are processed on the shop floor.

(iii)Aggregate Load First Only: This approach is newly introduced in this paper and uses: the total processing time units waiting in the pool to be released to the first (gateway) station; and, the throughput rate of this station, i.e. the maximum output per time unit. This recognizes that the gateway is the most tightly controlled station at order release. Note that the restriction to the first station for the corrected aggregate load measure is equivalent to this approach since the workload contribution is not converted for the first station.

\subsection{COBACABANA: A Comprehensive Card-Based System}

The overall COBACABANA system is depicted in Figure 2 where information loops are indicated by arrows; the different cards on the arrows represent the information being shared. COBACABANA operationalizes Workload Control by means of two card loops:

- Loop 1 - Order Release: The first card loop is from the pool to the shop floor. The release cards for each operation represent the shop floor workload, which is used by the planner for selecting jobs for release at the planning board. The corresponding operation cards move with the order and establish the feedback loop. When an operation is completed, the corresponding operation card is returned to the planning board and the corresponding release card is withdrawn.

- Loop 2 - Due Date Estimation at Customer Enquiry Management: The second card loop is between customer enquiry management and the pre-shop pool. The acceptance cards for each operation represent the pool load used to calculate due dates on the salesperson's 
display. The corresponding pool cards move with the order and establish the feedback loop. When the order is released from the pool, the pool cards return to the salesperson's display and the corresponding acceptance cards are removed.

[Take in Figure 2]

A comprehensive COBACABANA system, comprised of card-based due date setting and order release control, has recently been shown to significantly improve performance in a pure job shop by Thürer et al. (2015a). However, Thürer et al. (2015b) demonstrated that the release method applied in Thürer et al. (2015a) becomes dysfunctional in a pure flow shop and therefore needs to be adapted. In response, this study started by asking:

Does COBACABANA's due date estimation procedure have to be adapted in order for it to be effective in the pure flow shop?

Simulation is next used to answer this question and evaluate the performance of COBACABANA as a comprehensive system that supports due date setting and order release control in the pure flow shop.

\section{Simulation Model}

The shop and job characteristics modeled in the simulations are first outlined in Section 3.1. How order release control and due date estimations have been operationalized in the simulation are then discussed in sections 3.2 and 3.3, respectively. The priority dispatching rules applied on the shop floor are then described in Section 3.4. Note that COBACABANA controls the release of orders to the shop floor and not the progress of orders on the shop floor - this is exercised using a shop floor dispatching rule. Finally, the experimental design is outlined, and the measures used to evaluate performance are presented, in Section 3.5.

\subsection{Overview of Modeled Shop and Job Characteristics}

A simulation model of a pure flow shop (Oosterman et al., 2000) has been implemented in Python $^{\odot}$ using the SimPy ${ }^{\odot}$ module. Each job visits all stations in the same sequence in order of increasing station number. The shop contains six stations, where each station is a single resource with constant capacity. Operation processing times follow a truncated 2-Erlang distribution with a maximum of 4 time units and a mean of 1 time unit after truncation. Set-up times are 
considered part of the operation processing time. Meanwhile, the inter-arrival time of orders follows an exponential distribution with a mean of 1.111, which - based on the number of stations in the routing of an order - deliberately results in a utilization level of $90 \%$.

\subsection{COBACABANA - Order Release}

As in previous simulation studies on Workload Control and COBACABANA (e.g. Melnyk \& Ragatz, 1989; Land \& Gaalman, 1998; Fredendall et al., 2010; Thürer et al., 2014b), it is assumed that materials are available and all necessary information regarding shop floor routing, processing times, etc. is known upon the arrival of an order in the pool. Seven workload norm levels are applied, ranging from 4 to 10 time units. As a baseline measure, experiments without controlled order release have also been executed, i.e. where orders are released onto the shop floor immediately upon arrival.

\subsection{COBACABANA - Due Date Estimation at Customer Enquiry Management}

A due date is determined when the order arrives. Since it is rare that all due dates are either determined internally (i.e. fully under the control of the company) or set externally (i.e. always specified by a customer), five different due date setting scenarios are modeled. This allows us to assess the effect on performance of the mix of orders with due dates set internally and specified by the customer. The modeled ratios are as follows: $100 \%, 75 \%, 50 \%$, and $25 \%$ of due dates set using the internal due date estimation rule; and, no due dates set internally (i.e. 100\% of due dates set externally by the customer). The probability that a due date can be set internally for an order is modeled as a Bernoulli trial.

Internally (or endogenously) set due dates are determined by COBACABANA. Three different measures for the pool load are considered (see Section 2.2.1): (i) Aggregate Load, (ii) Corrected Load; and, (iii) Aggregate Load First Only. Each measure leads to a value for the pool waiting time allowance $(\alpha)$. The constant allowance for the shop floor throughput time $(\beta)$ is arbitrarily set to 30 time units, based on preliminary simulation experiments. Meanwhile, Hopp \& Sturgis (2000) compared the use of a constant external allowance with the use of alternative, dynamic external allowances. Numerical results suggested that there are no significant performance differences between the use of a constant allowance and the best-performing dynamic allowance approach. Therefore, a constant external allowance will be used in our study. To allow for comparison across experiments, the external allowance $(\gamma)$ was set through 
preliminarily simulation experiments such that the average of the quoted delivery lead time is 50 time units for all experiments. The quoted delivery lead time is defined as the customer due date minus the time the order was received.

Externally (or exogenously) set due dates specified by the customer are modeled by adding a random allowance factor, uniformly distributed between 40 and 60 time units, to the time when the order is received. Once the due date is determined, an order flows into the pre-shop pool to await release.

\subsection{Priority Dispatching Rule for the Shop Floor}

As in Thürer et al. (2015b), three dispatching rules will be considered in this study for controlling the flow of jobs on the shop floor: (i) the Operation Due Date (ODD) rule; (ii) the Shortest Processing Time (SPT) rule; and (iii) the Modified Operation Due Date (MODD) rule, which combines the SPT and ODD rules.

The calculation of the operation due date $d_{i j}$ for the $i^{\text {th }}$ operation of a job $j$ follows Equation (2) below. The operation due date for the last operation in the routing of a job is equal to the due date $d_{j}$, while the operation due date of each preceding operation is determined by successively subtracting a constant allowance $c$ from the operation due date of the next operation. The allowance has been set to 5 time units in this study. This value has been chosen based on preliminary simulation experiments, which indicated that it resulted in the best overall performance.

$d_{i j}=d_{j}-(6-i) \cdot c \quad i: 1 . .6$

The ODD rule prioritizes jobs with the earliest operation due date. Meanwhile, the SPT rule selects the job with the shortest processing time from the queue. Finally, the MODD rule prioritizes jobs according to the lowest priority number, which is given by the maximum of the operation due date and earliest finish time. In other words, $\max \left(d_{i j}, t+p_{i j}\right)$ for an operation with processing time $p_{i j}$, where $t$ refers to when the dispatching decision is made. The MODD rule shifts between a focus on ODDs to complete jobs on time and a focus on speeding up jobs through SPT effects - when multiple jobs exceed their ODD. 


\subsection{Experimental Design Factors and Performance Measures}

The experimental factors are: (i) the five different percentage levels for the proportion of due dates set internally by COBACABANA (100\%, 75\%, 50\%, 25\%; and 0\%, i.e. all due dates set externally by the customer); (ii) the three different load measures for due date estimation (aggregate, corrected, and aggregate load first only); (iii) the seven workload norm levels at order release (from 4 to 10 time units); and, (iv) the three dispatching rules (ODD, SPT and MODD). A full factorial design with 315 cells was used, where each cell was replicated 100 times. Results were collected over 10,000 time units following a warm-up period of 3,000 time units. These parameters allowed us to obtain stable results while keeping the simulation run time to a reasonable level.

Finally, three main performance measures are considered in this study: (i) the average lead time (i.e. the time when the order was completed minus the time when it arrived in the pool); (ii) the percentage of tardy orders; and, (iii) the standard deviation of lateness. The average lead time is used as the main indicator of the workload balancing capabilities. It also reflects the average lateness of orders, which can be derived directly from this measure and is equal to the realized average lead time minus the average delivery lead time (which is 50 time units across all experiments). The main indicator of delivery performance is the percentage of tardy orders, which is influenced by both the average lateness and the dispersion of lateness across orders. The latter is measured by the standard deviation of lateness.

In addition to the above three main performance measures, we also measure the average shop floor throughput time as an instrumental performance variable. While the lead time includes the time that an order waits in the pool prior to release, the shop floor throughput time only measures the time after release to the shop floor. According to Little's law, this is linked directly to the level of work-in-process.

\section{Results}

Statistical analysis has been conducted by applying ANOVA to give a first indication of the relative impact of our four experimental factors. ANOVA is here based on a block design, where the norm level is the blocking factor. Thus, statistical analysis is restricted to the main effects of order release, as each norm level can be considered to be a different system. The results are summarized in Table 1. All main effects, two-way interactions and the three-way-interactions 
related to percentage tardy and the standard deviation of lateness were shown to be statistically significant. Meanwhile, for lead time results, the measure used for due date estimation was shown to be not significant, as were most two-way and three-way interactions. As somewhat expected, the due date estimation procedure appears to have little impact on load balancing on the shop floor. Rather, it appears to impact the standard deviation of lateness the most. To further explore performance differences across our three measures for due date estimation, the Scheffé multiple comparison procedure was used. The results, as summarized in Table 2, confirm that there are no significant performance differences in terms of lead time. In terms of percentage tardy and the standard deviation of lateness, it can be observed that using the corrected load to estimate due dates performs the worst and that using the aggregate load to estimate due dates performs the best. Detailed performance results will be presented next in Section 4.1 for ODD dispatching before the performance impact of SPT and MODD dispatching is assessed in Section 4.2.

[Take in Table 1 and Table 2]

\subsection{The Performance of COBACABANA in the Pure Flow Shop (ODD Dispatching)}

Results are presented in the form of performance curves. Figure 3 (3a to 3d) summarizes the simulation results for ODD dispatching with 25\%, 50\%, 75\% and 100\% of the due dates set internally by the due date setting rule, respectively. All four figures include curves relating to each of the three main performance measures - the average lead time, standard deviation of lateness, and percentage of tardy orders - for all three load measures used to estimate due dates. Due dates based on the aggregate load are represented by the curves with square markers; due dates based on the corrected load are represented by the curves with round markers; and, due dates based on the aggregate load of the first (gateway) station only are represented by the curves with triangular markers. In addition, as a baseline, results for experiments where all due dates are set externally are represented by the curves with X markers. Each marker relates to the results of one experiment (i.e. workload norm level). The workload norm level is tightened (from 10 to 4 time units) by moving from right to left along each curve. Results for immediate release are also included. The separate marker X (i.e. not connected to the curves) on the right-hand side refers to immediate release with all due dates set externally. Meanwhile, the separate marker + refers to immediate release with all due dates set internally (i.e. set to 50 time units). 
The lead time is set on the primary vertical axis (i.e. the left-hand side scale) and reflected in the upper three dotted curves. The standard deviation of lateness is also set on the primary vertical axis and reflected in the middle three dashed curves. The lead time and the standard deviation of lateness are both measured in time units; hence, they can be measured on the same scale and axis. Finally, the percentage tardy is set on the secondary vertical axis (i.e. the righthand side scale) and reflected in the lower three solid curves.

[Take in Figure 3]

COBACABANA improves performance across all three performance measures compared to immediate release. Meanwhile, as expected setting due dates internally significantly enhances performance. This can be observed by moving from Figure 3a to 3d, i.e. by increasing the number of due dates set internally by COBACABANA's due date setting rule. Finally, in terms of our three measures for estimating due dates, it can be observed that:

- Using the highest aggregate load across stations outperforms the use of the aggregate load for the first station only. Despite this, it could be that, in practice, this small deterioration in performance is tolerated due to the simplicity of the latter approach.

- Using the corrected load performs best in terms of the percentage of tardy orders when $25 \%$ or $50 \%$ of due dates are set internally; otherwise, this approach leads to a significant deterioration in performance.

- There are no significant performance differences in terms of lead time performance across the three measures used to estimate due dates; therefore, performance differences must be explained by the standard deviation of lateness. This will be explored in further detail in Section 4.1.1 that now follows.

\subsubsection{Performance Analysis - Corrected Load Measure}

If the pool load is measured by the corrected load (i.e. the processing time divided by the position of a station in the routing of jobs), then the first station is the most likely to have the highest pool load. Since the pool waiting time is calculated based on the release rate measured in terms of the corrected load (which is based on the average routing position of stations across jobs (3.5)) the pool waiting time is inflated. This leads to both a higher average and greater dispersion of the estimated pool waiting times. In other words, due dates are shorter if the pool load is low but much longer if the pool load is high. If only some jobs suffer this consequence (i.e. the 
percentage of due dates determined internally is low), the overall impact can be positive. If there are few jobs in the pool and the due dates for jobs with internally set due dates are shorter, then externally set due dates can be postponed without this having a detrimental impact. Meanwhile, if the pool load is high, longer due dates for jobs with internally set due dates allow for more jobs with externally set due dates to be processed in time.

This explains why a positive effect is observed if there is a significant proportion of jobs with externally set due dates. However, performance significantly deteriorates if the majority of jobs have due dates determined internally, and thus quoted delivery lead times that are either extremely short or extremely long (compared to the actually realized delivery lead times).

There are two conclusions that can be drawn from this:

1. The use of the average routing position across stations for the release rate is not meaningful if the position of each station is fixed, such as in the pure flow shop. This means that each station should have its own release rate for calculating the expected pool waiting time.

2. If a different rate for each station is used, then the results obtained for the corrected measure closely follow the results obtained for the aggregate load first only measure. This is because the first (gateway) station is the station most likely to have the highest pool load. Note that this conjecture has been proven by additional simulation experiments (not presented here).

In the light of the above, the use of the corrected load - as proposed for pure job shops - is not justified in the pure flow shop since it either leads to dysfunctional behavior or performance results that approach those achieved using the simpler aggregate load measure of the first station only. There remains, however, the fact that the inflation of the estimated pool waiting time leads to significant performance improvements if the majority of jobs have due dates determined externally by the customer. This effect is achieved by using the internally set due date to shift work further into the future if the pool load is high. Since only a proportion of the work is shifted, a load balancing effect is realized, e.g. as in Melnyk et al. (1991) and Park \& Salegna (1995). In other words, work from a peak period is shifted to a future time period, which smoothens out peaks and valleys in the workload. However, we argue here that this should be a deliberate decision and not a side-effect of an inflated pool waiting time when estimating due dates. Future research is required to assess how this can be realized, where other factors like strike rates (e.g. as in Thürer et al. 2014a) and/or capacity adjustments are also considered. 


\subsection{Performance of COBACABANA - The Impact of SPT and MODD Dispatching}

Figures $4 \mathrm{a}$ to $4 \mathrm{~d}$ summarize the simulation results for SPT dispatching with 25\%, 50\%, 75\% and $100 \%$ of the due dates set internally by the due date setting rule, respectively. As expected, SPT dispatching significantly reduces throughput times and thus lead times compared to ODD dispatching. But this is at the expense of the standard deviation of lateness results. The effect of the SPT rule on this performance measure is so strong that the curves for the standard deviation of lateness lie above the lead time curves in Figure 4.

\section{[Take in Figure 4]}

The performance differences observed earlier (under ODD dispatching) for our three approaches to estimating due dates are maintained under SPT dispatching. However, (i) the corrected load measure loses its advantage when there is a high percentage of externally set due dates since the SPT rule does not consider the due dates of jobs; and, (ii) there is less distinction between the percentage tardy performance of the three measures, i.e. the curves move closer together. SPT reduces the percentage tardy by lowering the lead time and thus the average lateness. Since performance differences across our three approaches to estimating due dates mainly reside in the standard deviation of lateness, little difference can be observed in terms of the percentage tardy. However, it is expected that tighter due dates also lead to a significant deterioration for the corrected load measure in terms of the percentage tardy performance (when compared to the aggregate load measure) if the percentage of jobs with internally set due dates is high.

Finally, the simulation results for MODD dispatching are summarized in Figures $5 \mathrm{a}$ to $5 \mathrm{~d}$ for $25 \%, 50 \%, 75 \%$ and $100 \%$ of the due dates set internally by the due date setting rule, respectively. Again, performance differences for our three due date estimation measures are maintained. MODD combines ODD and SPT dispatching. It uses its ODD element to ensure the timely completion of jobs. Meanwhile, it uses its SPT element to speed up the progress of jobs when multiple jobs become urgent. This effect can be observed by comparing the throughput time results for immediate release (the right-hand single points in the figures) for MODD dispatching in Figure 5 with the results for ODD dispatching in Figure 3 (Section 4.1). There is a strong correlation between time periods of high workload and multiple jobs becoming urgent (Land et al., 2015). If due dates are determined based on the workload, as for COBACABANA, 
a second mechanism that reacts to a high workload is already in place - if workloads increase, so does the allowance for the pool waiting time $\alpha$. As a result, the performance difference between MODD and ODD dispatching, which can be observed by comparing the results when all due dates are set externally in Figure 3 and Figure 5, weaken if a certain percentage of due dates is set internally and the norm level is tight, i.e. most of the variability of the workload on the shop floor is reflected in the pool load. As a result, for the best-performing workload norm level, similar performance can be observed for MODD and ODD.

\section{[Take in Figure 5]}

From the above, two conclusions can be drawn:

1. Performance differences across our three measures used to estimate due dates are independent from the dispatching rule applied. This means that the simpler aggregate measure originally proposed in Land (2009) rather than the corrected load can and should be used in the pure flow shop.

2. The MODD and ODD rules result in similar performance if a certain percentage of due dates are set internally and the workload norm is set appropriately. Both dispatching rules are considered to be a better choice than SPT, which only improves percentage tardy performance at the expense of a high standard deviation of lateness. However, since MODD results in better performance at higher workload norm levels, it is considered to be the best choice for application in combination with COBACABANA in the pure flow shop in practice.

\section{Conclusions}

Card-based systems - most notably kanban, Constant Work-in-Process (ConWIP), and Pairedcell Overlapping Loops of Cards with Authorization (POLCA) - provide a simple, visual approach to controlling production. Yet, all three restrict themselves to controlling the shop floor. Other planning tasks - such as the estimation of short yet feasible due dates - are not supported. These tasks must be supported by other means, like MRP/ERP systems, which retain a considerable degree of sophistication in the planning process. This partly negates the advantage of simple, visual control. In response, Land (2009), Thürer et al. (2014b) and Thürer et al. (2015a) developed and refined COBACABANA - a card-based approach to Workload Control that integrates card-based due date estimation and order release control. But COBACABANA 
was developed for the pure job shop, and it has been unclear whether the approach translates directly across to the pure flow shop. In fact, Thürer et al. (2015b) recently demonstrated that COBACABANA's release mechanism needs to be adapted if it is to be applied to a pure flow shop. Complementing that study, we have asked: does COBACABANA's due date estimation procedure have to be adapted in order for it to be effective in the pure flow shop?

Using simulation, it has been shown that the corrected measure of the pool load for estimating due dates - as suggested for the pure job shop by Thürer et al. (2015a) - results in either artificially inflated estimated pool waiting times or a level of performance that can be replicated using the simpler aggregate measure of the pool load. This suggests that the simpler measure originally suggested by Land (2009) - can and should be maintained in the pure flow shop. Meanwhile, most of the performance improvement can be obtained by just considering the load waiting in the pool that is to be released to the first (gateway) station. This makes COBACABANA even simpler and further enhances its applicability to shops in practice.

\subsection{Managerial Implications and Future Research}

COBACABANA is, to the best of our knowledge, the first and only card-based production control approach that extends the use of cards to the estimation of due dates. It is argued here to be of particular importance to small shops, which are in need of a simple, visual and effective control solution. In our study, COBACABANA was used as an integrated system that combines due date setting with order release control. This was motivated by our focus on a pure flow shop with high variability in terms of the occurrence of demand and/or processing times. This type of environment will benefit the most from the unique load balancing capabilities of COBACABANA's release method. However, in less variable production environments, COBACABANA's due date estimation procedure could also be combined with alternative systems to control release - such as kanban, ConWIP and POLCA - since these also aim at stabilizing the work-in-process and thus shop floor throughput times. These systems may be simpler and thus preferable alternatives in more repetitive environments. Moreover, there will be many shops in practice that have already implemented, for example, kanban and can now 'add on’ additional card-based support for due date setting.

Finally, although we argue that using the corrected load measure to estimate pool waiting times is not meaningful in the pure flow shop, it did in fact significantly improve performance compared to the use of the aggregate load measure if the majority of jobs have a due date that is 
determined externally by the customer. We argued that this effect is caused by inflating the due dates of jobs with internally set due dates if the load in the pool is high, which results in shifting work from the current workload peak to a future valley. Future research should further explore this effect and determine how it can be translated into a useful management principle.

\section{References}

Aslan, B., Stevenson, M., and Hendry, L.C., 2015, The Applicability and Impact of Enterprise Resource Planning (ERP) Systems: Results from a Mixed Method Study on Make-To-Order (MTO) Companies, Computers in Industry, (Article in Press).

Bertrand, J.W.M, 1983, The use of workload information to control job lateness in controlled and uncontrolled release production systems, Journal of Operations Management, 3, 2, 79-92.

Enns, S. T., 1995, A dynamic forecasting model for job shop flow time prediction and tardiness control, International Journal Production Research, 33, 5, 1295-1312.

Fredendall, L.D., Ojha, D., and Patterson, J.W., 2010, Concerning the theory of workload control, European Journal of Operational Research, 201, 1, 99-111.

Hendry, L.C., Huang, Y., and Stevenson, M., 2013, Workload control: Successful implementation taking a contingency-based view of production planning \& control, International Journal of Operations \& Production Management, 33, 1, 69-103.

Hopp, W. J., and Spearman, M. L., 1996, Factory Physics, Richard D. Irwin, Boston, MA.

Hopp, W.J., and Sturgis, M.L.R., 2000, Quoting manufacturing due dates subject to a service level constraint, IIE Transactions, 32, 771-784.

Kanet, J.J., 1988, Load-limited order release in job shop scheduling systems, Journal of Operations Management, 7, 3, 44-58.

Krishnamurthy, A. and Suri R., 2009, Planning and implementing POLCA: a card-based control system for high variety or custom engineered products, Production Planning \& Control, 20, 7, 596-610.

Land, M.J., 2009, Cobacabana (control of balance by card-based navigation): A card-based system for job shop control, International Journal of Production Economics, 117, 97-103

Land, M.J., and Gaalman, G., 1998, The performance of workload control concepts in job shops: Improving the release method, International Journal of Production Economics, 56-57, 347-364.

Land, M.J., Stevenson, M., Thürer, M., and Gaalman, G.J.C., 2015, Job Shop Control: In Search of the Key to Delivery Improvements, International Journal of Production Economics, 168, 257-266.

Little, J., 1961, A proof of the theorem L $=\lambda \mathrm{W}$, Operations Research 8, 383-387. 
Melnyk, S.A., and Ragatz, G.L., 1989, Order review/release: research issues and perspectives, International Journal of Production Research, 27, 7, 1081-1096.

Melnyk, S.A., Ragatz, G.L., Fredendall, L., 1991, Load smoothing by the planning and order review/release systems: A simulation experiment, Journal of Operations Management,10, 4, 512523.

Oosterman, B., Land, M.L., and Gaalman, G., 2000, The influence of shop characteristics on workload control, International Journal of Production Economics, 68, 1, 107-119.

Park P.S. and Salegna, G.J., 1995, Load smoothing with feedback in a bottleneck job shop, International Journal of Production Research, 33, 6, 1549-1568.

Portioli-Staudacher, A., and Tantardini, M., 2011, A lean-based ORR system for non-repetitive manufacturing, International Journal of Production Research, 50, 12, 3257 - 3273.

Riezebos, J., Klingenberg, W., and Hicks, C., 2009 Lean Production and information technology: Connection or contradiction, Computers in Industry, 60, 237-247.

Riezebos, J., 2010, Design of POLCA material control systems, International Journal of Production Research, 48, 5, 1455-1477.

Shingo, S., 1989, A Study of the Toyota Production System from an Industrial Engineering Viewpoint, Cambridge, MA: Productivity Press.

Slomp, J., Bokhorst, J. A. C., and Germs, R., 2009, A lean production control system for highvariety/low-volume environments: a case study implementation, Production Planning \& Control, 20, 7, 586-595.

Spearman, M.L., Woodruff, D.L., and Hopp, W.J., 1990, CONWIP: a pull alternative to kanban, International Journal of Production Research, 28, 5, 879-894.

Spearman, M.L., Hopp, W.J., and Woodruff, D.L., 1989, An hierarchical control architecture for Constant Work-in-Process (CONWIP) Production Systems, Journal of Manufacturing and Operations Management, 2, 147-171.

Sugimori, Y., Kusunoki, K., Cho., F., and Uchikawa, S., 1977, Toyota production system and Kanban system Materialization of just-in-time and respect-for-human system, International Journal of Production Research, 15, 6, 553-564.

Suri, R., 1998, Quick Response Manufacturing: A Companywide Approach to Reducing Lead Times, Productivity Press, Portland, OR.

Suri, R., 2003, QRM and POLCA: A Winning Combination for Manufacturing Enterprises in the $21^{\text {st }}$ Century, Technical Report, Center for Quick Response Manufacturing, May 2003. 
Thürer, M., Stevenson, M., Silva, C., Land, M.J., and Fredendall, L.D., 2012, Workload control (WLC) and order release: A lean solution for make-to-order companies, Production \& Operations Management, 21, 5, 939-953.

Thürer, M., Stevenson, M., Silva, C., Land, M.J., Fredendall, L.D., and Melnyk, S.A., 2014a, Lean Control for Make-to-Order Companies: Integrating Customer Enquiry Management and Order Release, Production \& Operations Management, 23, 3, 463-476.

Thürer, M., Land, M.J., and Stevenson, M., 2014b, Card-Based Workload Control for Job Shops: Improving COBACABANA, International Journal of Production Economics, 147, 180-188.

Thürer, M., Land, M.J., Stevenson, M., and Fredendall, L.D., 2015a, Card-Based Delivery Date Promising in High-Variety Manufacturing with Order Release Control, International Journal of Production Economics, (in print)

Thürer, M., Stevenson, M., and Protzman, C.W., 2015b, COBACABANA (Control of Balance by Card Based Navigation): An Alternative to Kanban in the Pure Flow Shop?, International Journal of Production Economics, 166, 143-151

White, R.E., and Prybutok, V., 2001, The relationship between JIT practices and type of production system, Omega, 29, 113-124.

White, R.E., Pearson, J.N., and Wilson, J.R., 1999, JIT manufacturing: A survey of implementation in small and large US manufacturers, Management Science, 45, 1, 1-15. 
Table 1: ANOVA Results

\begin{tabular}{|c|c|c|c|c|c|c|}
\hline $\begin{array}{l}\text { Performance } \\
\text { Measure }\end{array}$ & Source of Variance & $\begin{array}{l}\text { Sum of } \\
\text { Squares }\end{array}$ & $\begin{array}{c}\text { Degree of } \\
\text { Freedom }\end{array}$ & $\begin{array}{r}\text { Mean } \\
\text { Squares }\end{array}$ & F-Ratio & $\begin{array}{c}p- \\
\text { Value }\end{array}$ \\
\hline \multirow{9}{*}{ Lead Time } & $\%$ Due Dates Set (\%DD) & 1570.61 & 4 & 392.65 & 54.14 & 0.000 \\
\hline & Measure DD Estimation (MDD) & 17.79 & 2 & 8.89 & 1.23 & 0.293 \\
\hline & Norm Level & 8013.59 & 6 & 1335.60 & 184.15 & 0.000 \\
\hline & Dispatching Rule & 1181682.65 & 2 & 590841.33 & 81465.26 & 0.000 \\
\hline & $\% \mathrm{DD} \times \mathrm{MDD}$ & 33.17 & 8 & 4.15 & 0.57 & 0.802 \\
\hline & \%DD x Dispatching & 479.66 & 8 & 59.96 & 8.27 & 0.000 \\
\hline & MDD x Dispatching & 20.79 & 4 & 5.19 & 0.72 & 0.580 \\
\hline & \%DD x MDD x Dispatching & 113.31 & 16 & 7.08 & 0.98 & 0.480 \\
\hline & Error & 228089.48 & 31449 & 7.25 & & \\
\hline \multirow{9}{*}{$\begin{array}{l}\text { Percentage } \\
\text { Tardy }\end{array}$} & $\%$ Due Dates Set (\%DD) & 4.22 & 4 & 1.06 & 805.73 & 0.000 \\
\hline & Measure DD Estimation (MDD) & 0.28 & 2 & 0.14 & 105.19 & 0.000 \\
\hline & Norm Level & 5.45 & 6 & 0.91 & 693.28 & 0.000 \\
\hline & Dispatching Rule & 9.82 & 2 & 4.91 & 3746.59 & 0.000 \\
\hline & $\% \mathrm{DD} \times \mathrm{MDD}$ & 2.23 & 8 & 0.28 & 212.75 & 0.000 \\
\hline & $\% \mathrm{DD} \times$ Dispatching & 1.99 & 8 & 0.25 & 190.08 & 0.000 \\
\hline & MDD x Dispatching & 0.144 & 4 & 0.04 & 27.40 & 0.000 \\
\hline & \%DD x MDD x Dispatching & 1.47 & 16 & 0.09 & 70.03 & 0.000 \\
\hline & Error & 41.20 & 31449 & 0.001 & & \\
\hline \multirow{9}{*}{$\begin{array}{c}\text { Standard } \\
\text { Deviation (SD) } \\
\text { of Lateness }\end{array}$} & \% Due Dates Set (\%DD) & 19678.31 & 4 & 4919.58 & 339.86 & 0.000 \\
\hline & Measure DD Estimation (MDD) & 30469.64 & 2 & 15234.82 & 1052.46 & 0.000 \\
\hline & Norm Level & 7793.76 & 6 & 1298.96 & 89.74 & 0.000 \\
\hline & Dispatching Rule & 727994.56 & 2 & 363997.28 & 25145.83 & 0.000 \\
\hline & $\% \mathrm{DD} \times \mathrm{MDD}$ & 44280.05 & 8 & 5535.01 & 382.37 & 0.000 \\
\hline & \%DD $\times$ Dispatching & 3763.53 & 8 & 470.44 & 32.49 & 0.000 \\
\hline & MDD x Dispatching & 1128.19 & 4 & 282.05 & 19.49 & 0.000 \\
\hline & \%DD x MDD x Dispatching & 3440.93 & 16 & 215.06 & 14.86 & 0.000 \\
\hline & Error & 455238.52 & 31449 & 14.48 & & \\
\hline
\end{tabular}

Table 2: Results for Scheffé Multiple Comparison Procedure

\begin{tabular}{|c|c|c|c|c|c|c|c|}
\hline \multirow{2}{*}{$\begin{array}{l}\text { Measure Due Date } \\
\text { Estimation }(x)\end{array}$} & \multirow{2}{*}{$\begin{array}{l}\text { Measure Due Date } \\
\text { Estimation (y) }\end{array}$} & \multicolumn{2}{|c|}{ Lead Time } & \multicolumn{2}{|c|}{ Percentage Tardy } & \multicolumn{2}{|c|}{ SD of Lateness } \\
\hline & & lower $^{1)}$ & upper & lower & upper & lower & upper \\
\hline Aggre & Aggregate $1^{\text {st }}$ only & -0.034 & $0.148^{\star}$ & -0.006 & -0.003 & -0.481 & -0.224 \\
\hline Aggregate & Corrected & -0.051 & $0.131^{*}$ & -0.008 & -0.006 & -2.369 & -2.112 \\
\hline Aggregate $1^{\text {st }}$ only & Corrected & -0.108 & $0.074^{*}$ & -0.004 & -0.001 & -2.016 & -1.759 \\
\hline
\end{tabular}




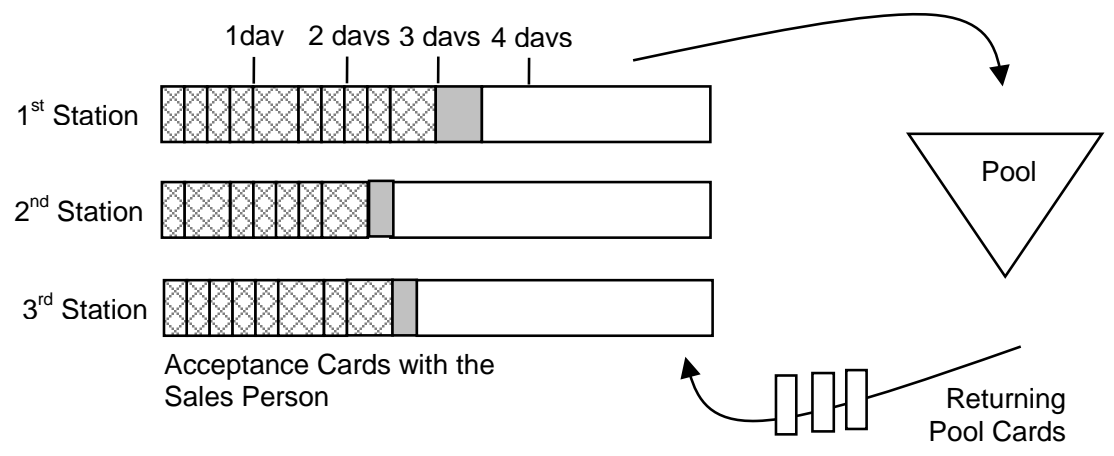

Figure 1: Card-based Customer Enquiry Management - The Salesperson’s Display

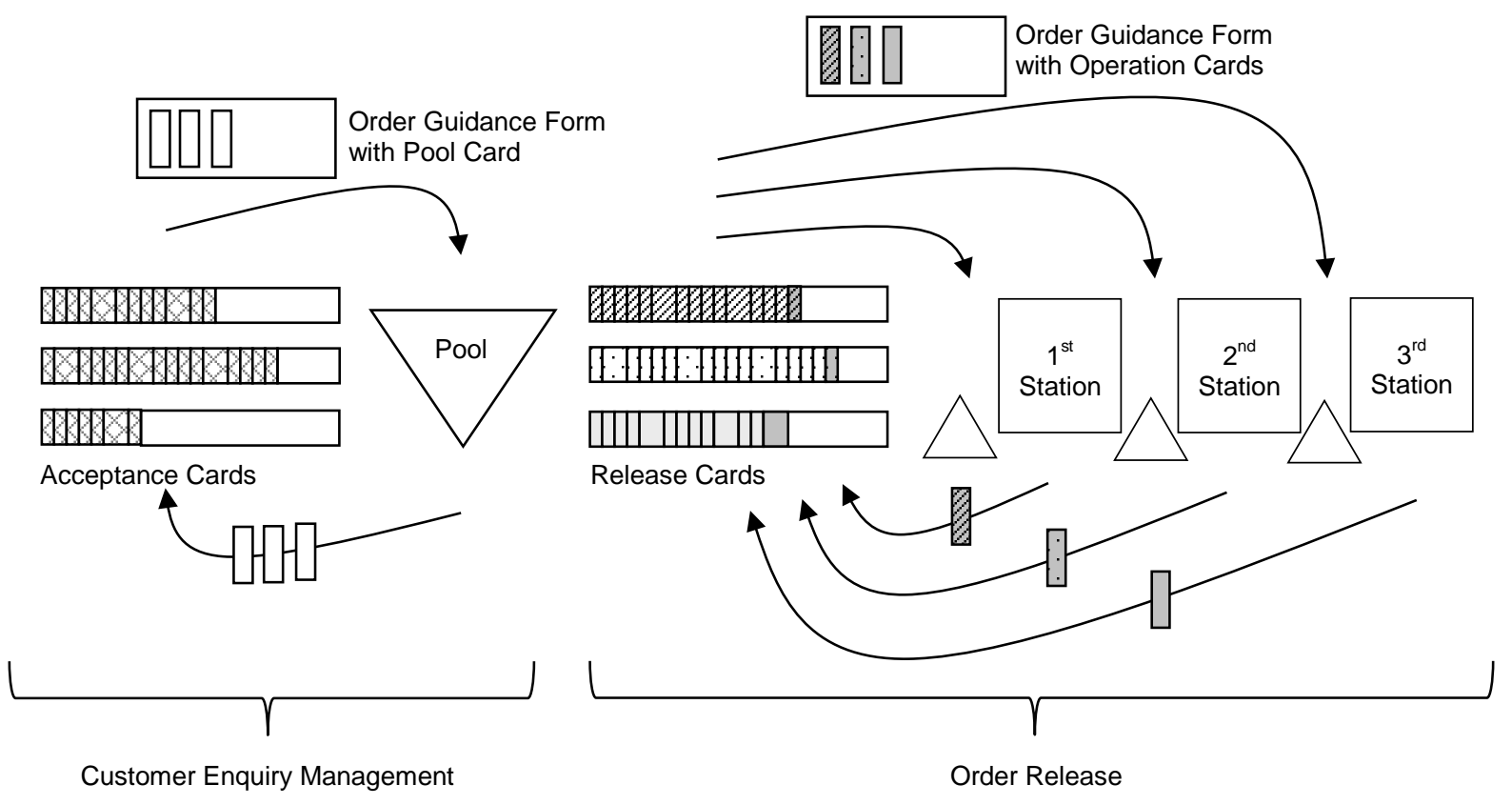

Figure 2: Integrated COBACABANA (from Thürer et al., 2015a) - Card Loops between the Salesperson at Customer Enquiry Management \& Order Release; and between the Planner at Order Release \& Stations on the Shop Floor 


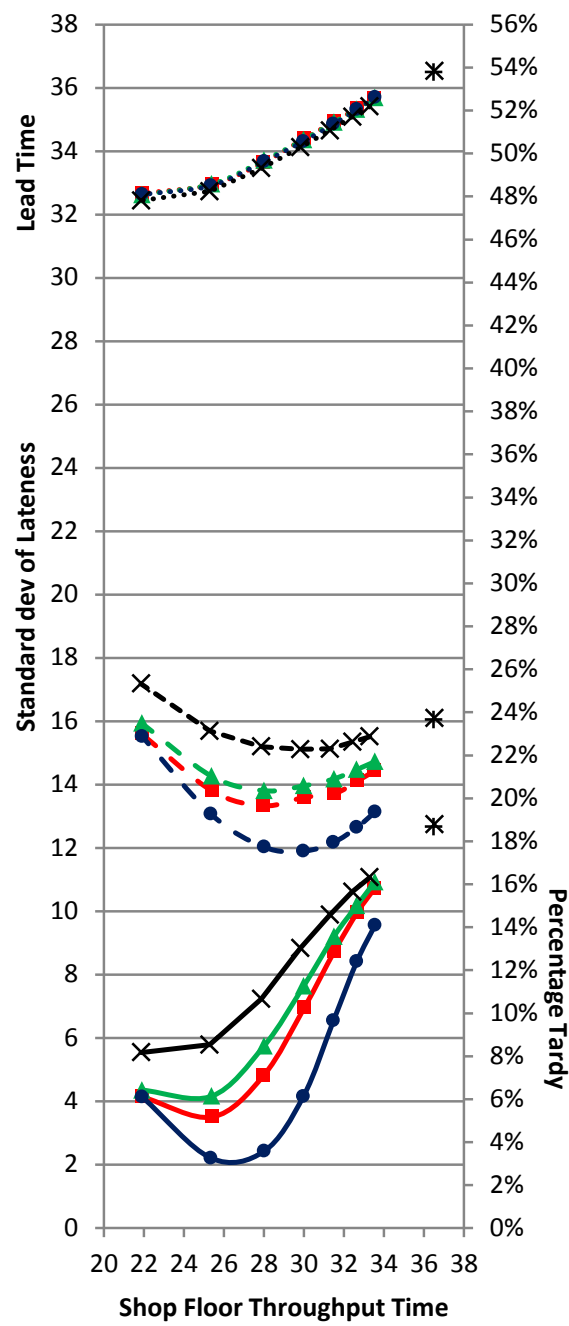

(a) $25 \%$ DD set Internally

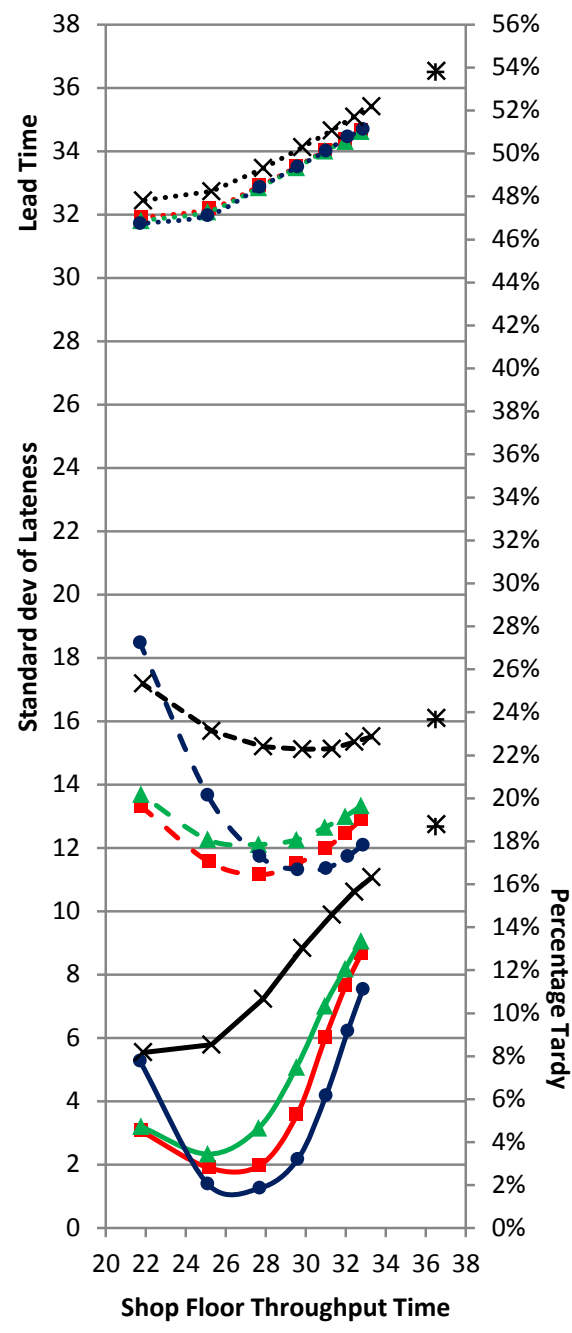

(b) $50 \%$ DD set Internally

........ Lead Time - aggregate load - - SD late - aggregate load

....... Lead Time - corrected load - - SD late - corrected load $\longrightarrow$ Tardy - corrected load

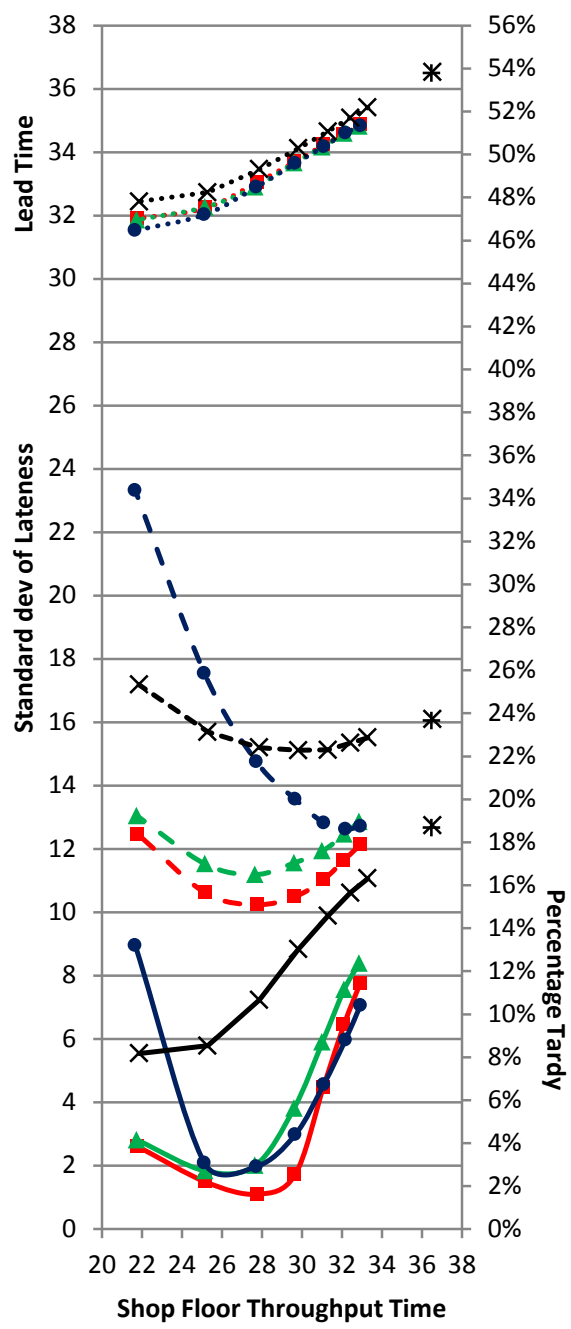

(c) $75 \%$ DD set Internally

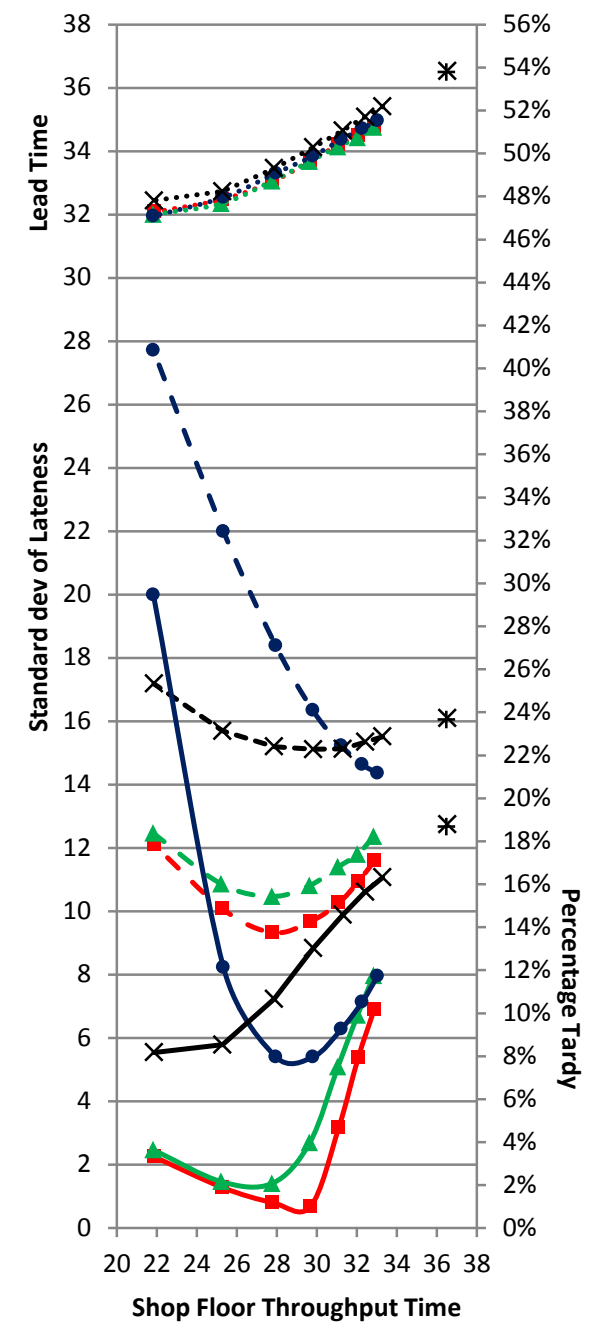

(d) $100 \%$ DD set Internally
….... Lead Time - aggregate 1 st only $\quad \ldots \ldots \ldots$... lead time - all external

- \pm- SD late - aggregate 1st only $\quad$ - $-*-$ - SD late - all external $\longrightarrow \%$ Tardy - aggregate 1st only $\quad \longrightarrow$ \% Tardy - all external

Figure 3: Performance Results for ODD Dispatching with 25\%, 50\%, 75\% and 100\% of Due dates Set Internally 


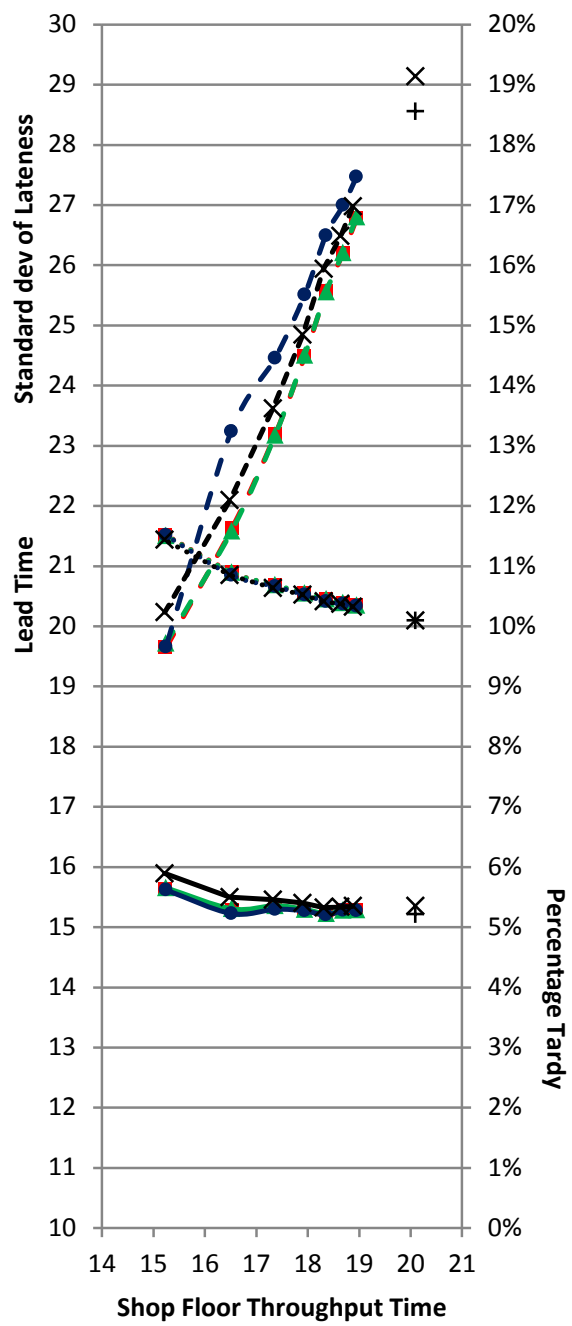

(a) $25 \%$ DD set Internally

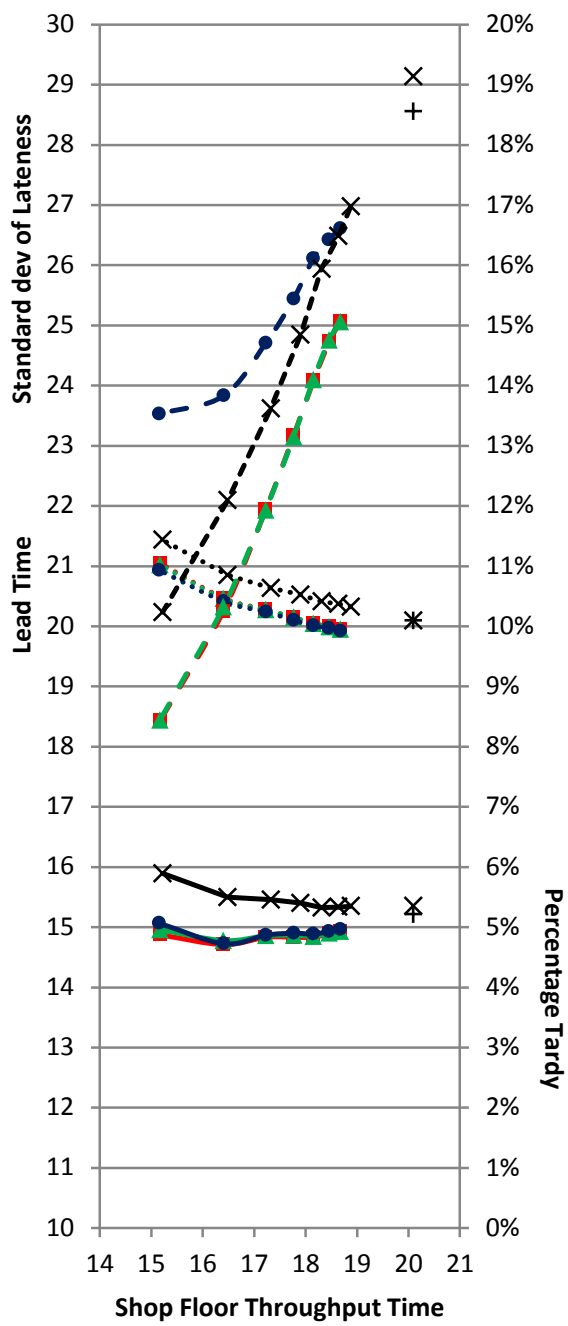

(b) $50 \%$ DD set Internally

........ Lead Time - aggregate load - - SD late - aggregate load

....... Lead Time - corrected load - - SD late - corrected load $\longrightarrow$ T Tardy - corrected load

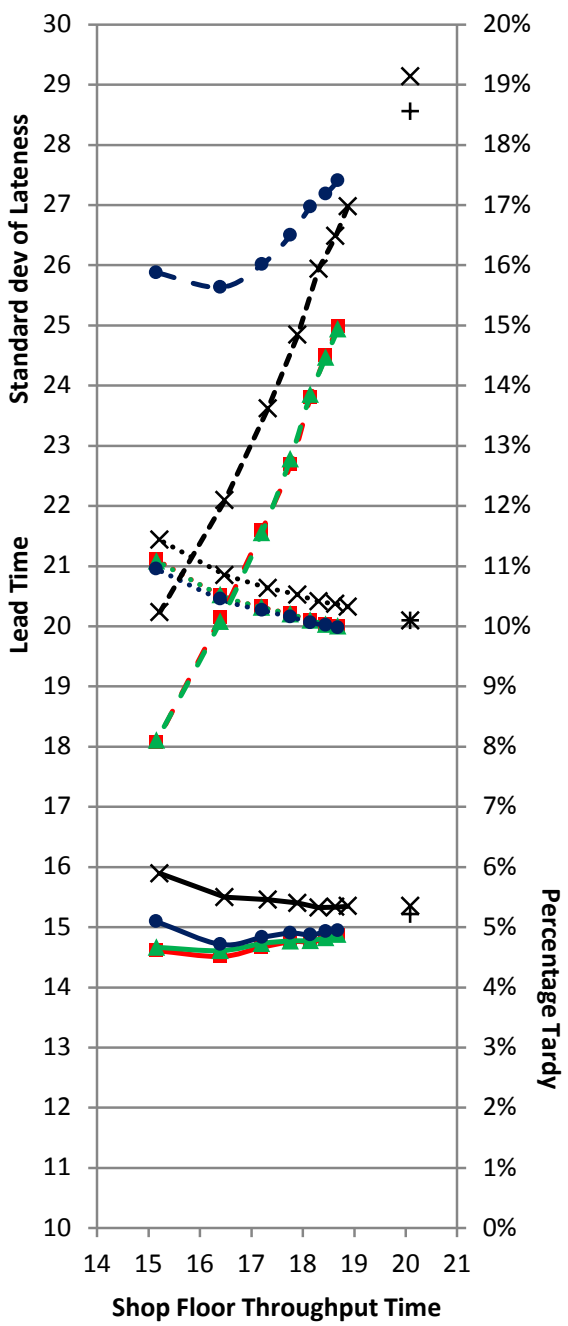

(c) $75 \% \mathrm{DD}$ set Internally

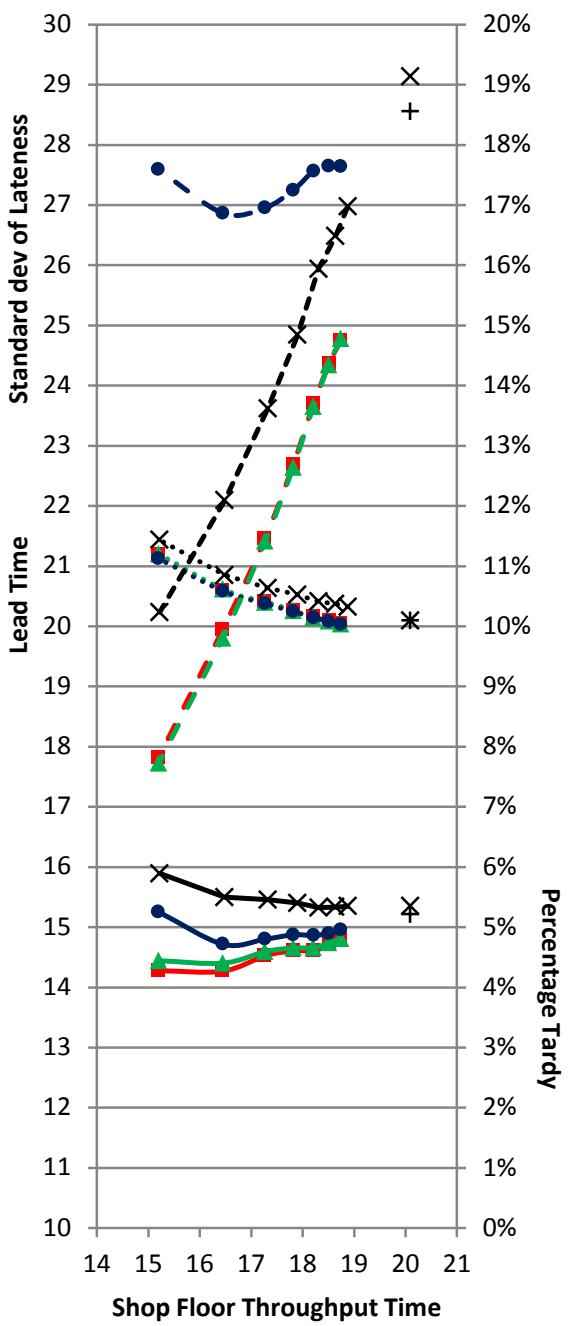

(d) $100 \%$ DD set Internally

........ Lead Time - aggregate 1 st only $\quad \ldots . \cdots \cdots$ lead time - all external

$-\ldots-$ SD late - aggregate 1st only $\quad$ - $-\star--S D$ late - all external

$\longrightarrow \%$ Tardy - aggregate 1st only $\quad \longrightarrow$ \% Tardy - all external

Figure 4: Performance Results for SPT Dispatching with 25\%, 50\%, 75\% and 100\% of Due dates Set Internally 


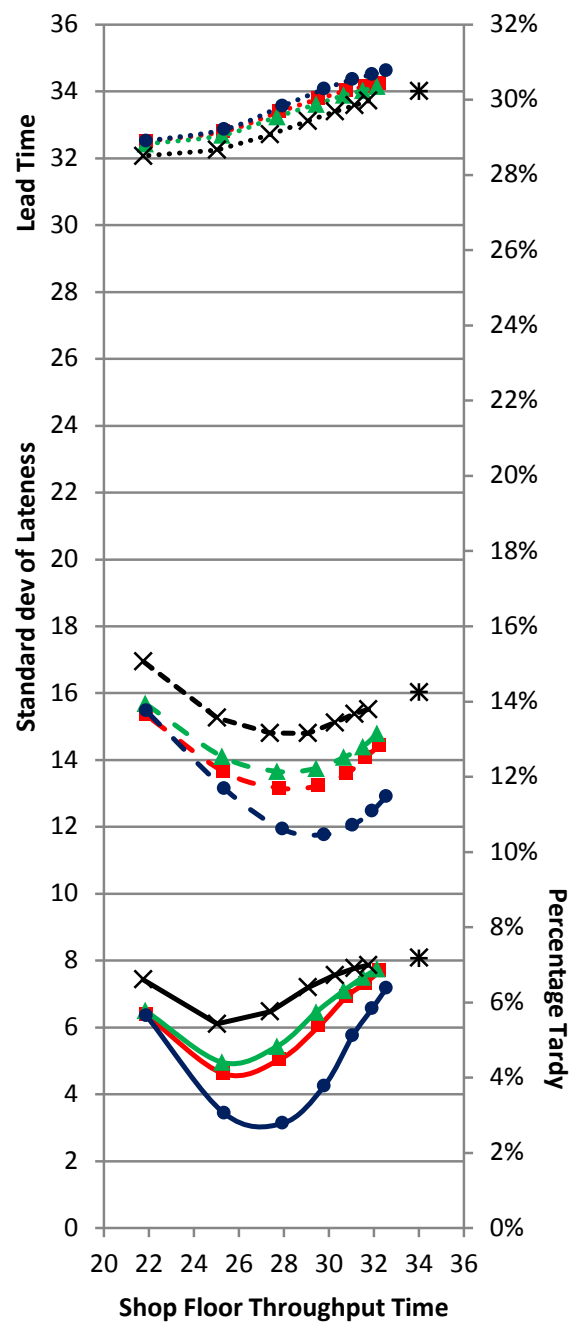

(a) $25 \%$ DD set Internally

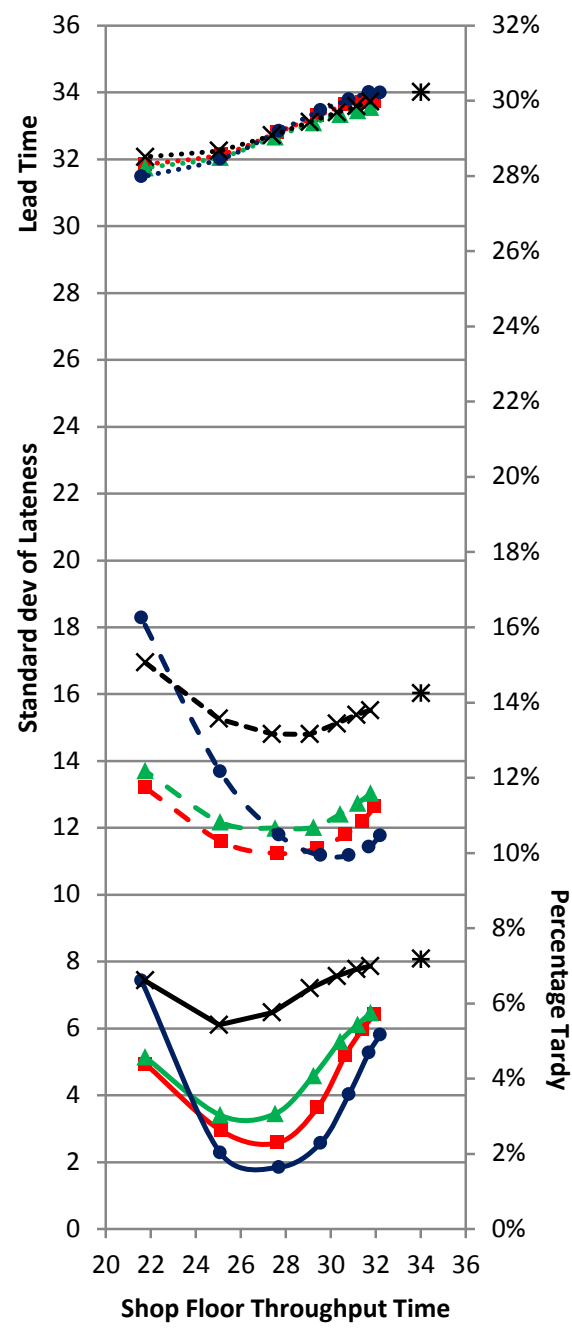

(b) $50 \%$ DD set Internally

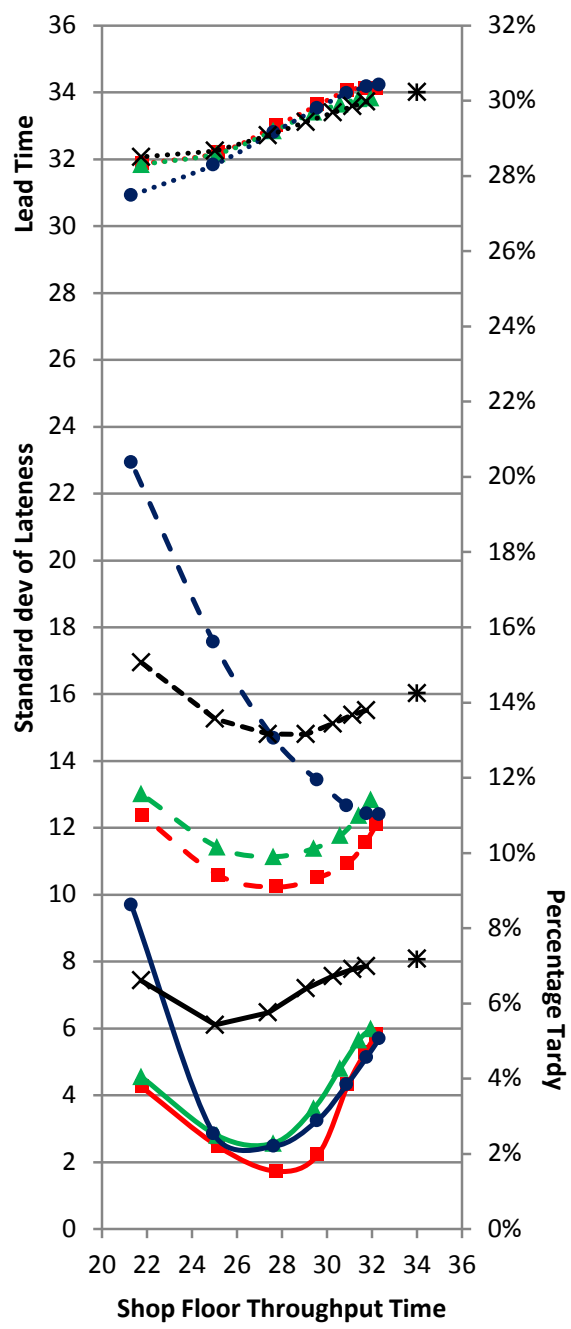

(c) $75 \%$ DD set Internally

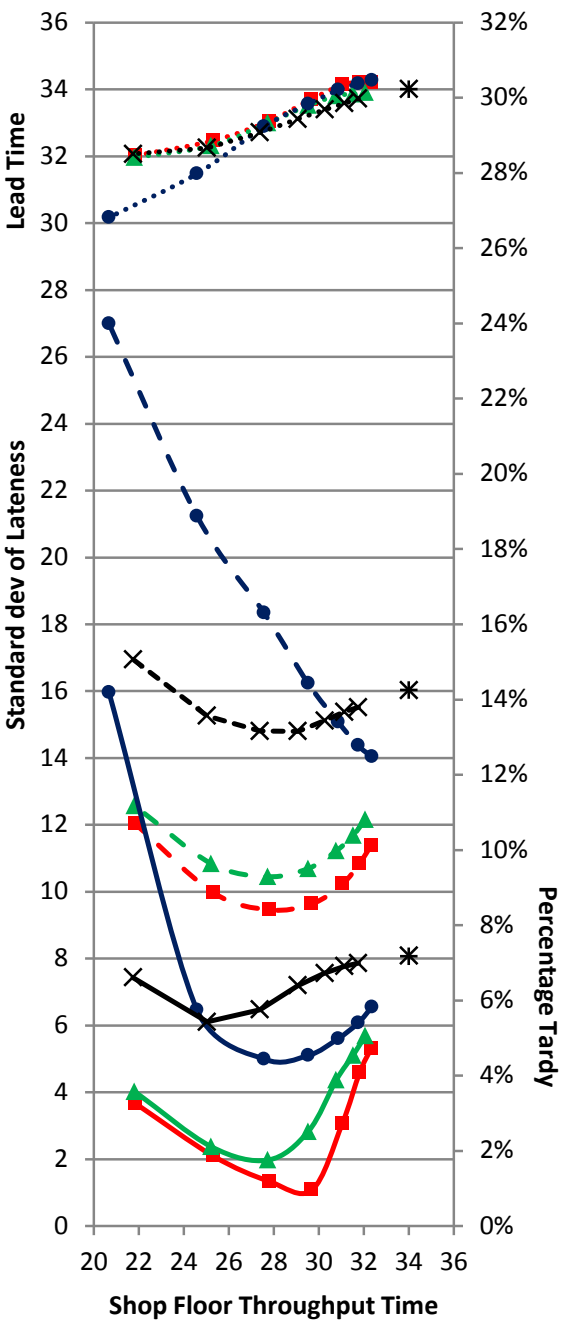

(d) $100 \%$ DD set Internally

........ Lead Time - aggregate load - - SD late - aggregate load

....... Lead Time - corrected load - - SD late - corrected load $\longrightarrow$ \% Tardy - corrected load

....... Lead Time - aggregate 1st only $\ldots . . . \times \ldots$ lead time - all externa $-\neq-$ SD late - aggregate 1 st only $\quad$ - $-*--$ SD late - all external $\longrightarrow \%$ Tardy - aggregate 1st only $\quad \longrightarrow$ \% Tardy - all external

Figure 5: Performance Results for MODD Dispatching with 25\%, 50\%, 75\% and 100\% of Due dates Set Internally 